\title{
Pengaruh Group Cognitive Behavior Therapy (GCBT) terhadap Perubahan Perilaku Remaja Berisiko Penyalahgunaan NAPZA Berdasarkan StatusTempat Tinggal di Kabupaten Dharmasraya Tahun 2019
}

\author{
Wisdia Lola Erwinda ${ }^{1}$, Sumiati ${ }^{2}$, Heppi Sasmita ${ }^{3}$ \\ ${ }^{1}$ Program Studi S2 Keperawatan, Fakultas Keperawatan Universitas Andalas \\ 2Fakultas Keperawatan Universitas Andalas \\ ${ }^{3}$ Politeknik Kesehatan Kementerian Kesehatan RI \\ 1Correspondence e-mail: lolafaisal_nurse@yahoo.com, ²email: susmiati@ners.unand.ac.id, 3email: heppi_sasmita@yahoo.com
}

\begin{abstract}
Abstrak. Latar Belakang: Kabupaten Dharmasraya sangat rawan dan rentan sekali dengan kasus peredaran narkoba karena Kabupaten Dharmasraya terdiri dari berbagai etnis dan merupakan daerah perlintasan lintas Sumatera sehingga diperlukan cara untuk mencegah perilaku penyalahgunaan NAPZA pada remaja. Tujuan: Tujuan penelitian ini adalah untuk mengetahui pengaruh Group Cognitive Behaviour Therapy (GCBT) terhadap perubahan perilaku remaja berisiko penyalahgunaan NAPZA berdasarkan status tempat tinggal di Kabupaten Dharmasraya Tahun 2019. Metode: Desain penelitian ini adalah Quasi Eksperimen PreTest PostTest With Control Group dengan jumlah sampel 64 orang yang terdiri dari 32 kelompok kontrol dan 32 kelompok intervensi. Hasil: Hasil penelitian pada kelompok intervensi dan remaja dengan status tempat tinggal bersama orang tua menunjukkan ada pengaruh yang signifikan terhadap perubahan perilaku remaja. Sedangkan pada kelompok kontrol dan pada remaja dengan status tempat tinggal tidak bersama orang tua tidak terdapat perbedaan yang signifikan. Kesimpulan: Group Cognitive Behaviour Therapy (GCBT) dapat digunakan untuk merubah perilaku remaja berisiko penyalahgunaan NAPZA. Diharapkan GCBT dapat dilaksanakan di sekolah-sekolah bekerjasama dengan dinas kesehatan serta orang tua untuk mencegah perilaku penyalahgunaan NAPZA pada remaja.
\end{abstract}

Kata kunci: Group Cognitive Behaviour Therapy; Karakteristik Status Tempat; Perilaku Remaja Berisiko Penyalahgunaan NAPZA

Abstract. Background: Dharmasraya District is very prone and vulnerable to drug circulation cases because Dharmasraya district consists of various ethnic and is a cross-Sumatran crossing area so it is necessary to prevent the behavior of abuse NAPZA on adolescent. Purpose: This study aimed to determine the influence of the Group Cognitive Behaviour Therapy (GCBT) on the change of adolescent behaviour at risk of drugs based on residential status in Dharmasraya District in 2019. Method: The design of this research is the Quasi experiment of PreTest PostTest With Control Group by the amounts of samples 64 consisting of 32 control groups and 32 intervention groups. Results: Research on the intervension group and adolescent living with parents showed significant influence on adolescent behaviour changes. Whereas in the control group and adolescent who do not live with parents showed no significant influence on adolescent behaviour changes Conclusion: Group Cognitive Behavior Therapy can be used to change adolescent behavior at risk of drugs abuse and Hopefully the implementation of cognitive behaviour therapy can be applied at schools in cooperation with health service and parents to prevent risky behaviour.

Keywords: Adolescent behaviour risky abuse of drugs; Group Cognitive Behaviour Therapy; Residential Status characteristics

\section{PENDAHULUAN}

Masalah kesehatan usia remaja merupakan salah satu masalah penting dari siklus kehidupan. Salah satu faktor risiko perilaku yang berperan dalam status kesehatan usia remaja adalah konsumsi minuman beralkohol dan pemakaian obat-obatan terlarang atau penyalahgunaan zat yang dikenal dengan penyalahgunaan Narkoba, Psikotropika dan Zat Adiktif lainnya. Diperkirakan jumlah penyalahgunaan narkoba meningkat menjadi 5 juta orang pada tahun 2020. Hal tersebut menjadikan Indonesia sebagai negara yang memiliki peringkat teratas dalam peredaran narkotika (BNN, 2015).

Menurut Penelitian (Peltzer \& Ah, 2017) menyatakan remaja yang berisiko penyalahgunaan NAPZA adalah remaja yang perokok aktif, peminum alkohol, tingkat pendidikan orang tua rendah, status sosial ekonomi rendah, tingkat stres tinggi, depresi, pengalaman mendapatkan dan melakukan kekerasan, dan tinggal di daerah pedesaan atau kota kecil. Sedangkan penelitian dari (Sitorus, 2016) menyebutkan pengguna narkotika sebelumnya memiliki kebiasaan minum alkohol yaitu sebesar $76 \%$, memiliki kebiasaan minum alkohol sampai mabuk sebesar $51,3 \%$. Sejalan dengan pendapat (Thomas \& Rockwood, 2001) yang mengatakan bahwa beberapa penelitian menunjukkan penyalahgunaan NAPZA membawa dampak buruk terhadap perilaku dan fungsi kognitif para penggunanya.

Menurut (Sudarsono, 2004) keluarga dan tempat tinggal memiliki peranan penting dalam perkembangan anak. Keluarga atau tempat tinggal yang baik akan berpengaruh positif bagi perkembangan anak, karena sejak kecil anak telah dibesarkan oleh keluarga maka dapat dikatakan bahwa kenakalan remaja sebagian besar dari tempat tinggal. Tinggal bersama orang tua memiliki arti bahwa individu hidup bersama dalam satu rumah bersama orangtua nya sehingga lebih banyak mendapat bimbingan, perhatian, dan kasih sayang.

Salah satu upaya yang bersifat strategis dalam penanggulangan penyalahgunaan NAPZA adalah upaya pencegahan dengan meningkatkan upaya promotif dan preventif. Menurut Willner, Assessment of substance Misuse in Adolescence (ASMA) dapat menjadi instrumen penyaringan yang bermanfaat untuk mengidentifikasi masalah penggunaan narkoba pada remaja yang tidak diketahui oleh layanan perawatan (Willer, 2000).

Kabupaten Dharmasraya terdiri dari berbagai etnis dan merupakan daerah perlintasan lintas Sumatera. Melihat kondisi daerah Kabupaten 
Dharmasraya yang terletak di daerah perbatasan Provinsi Sumatera Barat dengan Kabupaten Muaro Bungo Provinsi Jambi dan Kabupaten Teluk Kuantan Provinsi Riau, sangat rawan serta rentan sekali dengan kasus peredaran narkoba. Sampai saat ini belum pernah dilakukan psikoterapi untuk mencegah penyalahgunaan NAPZA pada remaja di Kabupaten Dharmasraya seperti Cognitive Behaviour Therapy (CBT) untuk mengatasi permasalahan remaja berisiko penyalahgunaan NAPZA. Menurut (Martin, 2010) Cognitive Behaviour Therapy (CBT) merupakan suatu terapi psikososial yang mengintegrasikan modifikasi perilaku melalui pendekatan restrukturisasi kognitif Fokus terapi menurut Sochting adalah pada penghargaan diri/ reinforcement positif, penetapan tujuan, modifikasi perilaku, dan latihan ketrampilan agar terapi ini dapat dijadikan intervensi alami bagi anak (Sochting, 2004).

Hasil penelitian dari (Esposito-smythers, Hadley, Curby, \& Brown, 2017) menunjukkan bahwa CBT efektif digunakan untuk pencegahan pada remaja dengan perilaku minum-minuman alkohol, melukai diri, dan penderita HIV dimana setelah diberikan CBT terdapat perubahan perilaku pada remaja secara signifikan. Sejalan dengan penelitian yang dilakukan oleh (Hargiana, dkk 2018) yang menunjukkan bahwa CBT juga dapat diberikan pada klien perokok, ketergantungan nikotin, dan kecemasan, kelompok yang mendapat CBT mengalami penurunan secara signifikan.

Penelitian oleh (Ardashir \& Nazafarin, 2018) menunjukkan bahwa terapi kognitif perilaku secara kelompok yang dilakukan selama 4 minggu terbukti mampu menurunkan skor ide bunuh diri pada pasien di Rumah Sakit dengan depresi. Jadi bisa disimpulkan terapi kognitif perilaku kelompok memberikan efektifitas yang sama dengan terapi kognitif perilaku individu dan dapat dilakukan untuk remaja.

Diharapkan Group Cognitive Behaviour Therapy (GCBT) mampu memperbaiki perilaku remaja yang bermasalah sehingga muncul perilaku yang terarah dan diharapkan. Terapi ini belum pernah dilakukan di sekolah yang ada di Kabupaten Dharmasraya dalam mencegah perilaku berisiko penyalahgunaan NAPZA pada remaja. Berdasarkan uraian tersebut maka peneliti tertarik untuk meneliti apakah ada pengaruh GCBT terhadap perubahan perilaku remaja berisiko NAPZA di Kabupaten Dharmasraya Tahun 2019.

\section{METODE PENELITIAN}

Desain penelitian ini adalah Pre Test and Post Test Two Group Design, dengan rancangan Quasy Experimental. Penelitan ini membandingkan dua kelompok remaja yang berisiko penyalahgunaan NAPZA. Teknik pengambilan sampel dalam penelitian ini adalah teknik purposive sampling. Perhitungan besar sampel pada penelitian ini menggunakan rumus (Dharma K.K, 2011) sebagai berikut:

$$
\left[\frac{n=\left(Z_{1-\frac{\alpha}{2}+} Z_{1-\beta}\right) X \sigma^{2}}{\mu_{1}-\mu_{2}}\right]
$$

Keterangan rumus:

$\mathrm{n} \quad$ : Jumlah sampel

$\mathrm{Z}_{1}-\alpha /{ }_{2}$ : Standar normal deviasi untuk a (standar normal $=1,96$ )

$Z_{1-\beta} \quad$ : Standar normal deviasi untuk $\beta$ (standar normal $=1,282)$

$\mu_{1}-\mu_{2} \quad$ : Beda mean yang dianggap bermakna secara klinik antara sebelum perlakuan (pre test) dan setelah perlakuan (post test) menurut Apriliyanti adalah $\left(\mu_{1}=8.35\right)\left(\mu_{2}=10.90\right)$

$\sigma \quad$ : Estimasi standar deviasi dari beda mean data pre test dan post test berdasarkan literature menurut Apriliyanti adalah 2.55

Perhitungan besar sampel adalah sebagai berikut:

$$
\begin{array}{ll}
\mathrm{n}=\left[\frac{\left(z_{1-\frac{\alpha}{2}+} z_{1-\beta}\right) X \sigma^{2}}{\mu_{1}-\mu_{2}}\right] \\
\mathrm{n} & =\left[\frac{(1,96+1,282) X 2,55^{2}}{1,531}\right] \\
\mathrm{n} & =\left[\frac{8,26}{1,531}^{2}\right] \\
\mathrm{n} & =(5,39)^{2} \\
\mathrm{n} & =29
\end{array}
$$

Untuk mengantisipasi kemungkinan subjek terpilih drop out perlu dilakukan koreksi terhadap besar sampel dengan menambahkan sejumlah subjek dengan menggunakan rumus:

$\mathrm{n}^{\prime}=\frac{n}{1-f}$

\section{Keterangan:}

$\mathrm{n}^{\prime} \quad=$ ukuran sampel setelah direvisi

$\mathrm{n} \quad=$ ukuran sampel asli

1-f $\quad=$ Perkiraan proporsi drop out, yang diperkiran $10 \%(\mathrm{f}=0,1)$

$$
\begin{aligned}
\mathrm{n}^{\prime} & =\frac{29}{0,9} \\
\mathrm{n}^{\prime} & =32 \times 2 \\
& =64 \text { orang (32 orang untuk kelompok intervensi } \\
& \text { dan } 32 \text { orang untuk kelompok kontrol) }
\end{aligned}
$$

Peneliti mengambil sampel pada wilayah kerja Puskesmas Sitiung I sebagai kelompok intervensi dengan jumlah sampel sebanyak 32 orang dari populasi 330 orang siswa, sedangkan untuk kelompok kontrol peneliti mengambil SMPN 02 Pulau Punjung SMAN 02 Pulau Punjung dengan jumlah sampel 32 orang dari populasi 211 orang siswa, secara karakteristik responden yang sama dengan kelompok intervensi, yaitu mempunyai kunjungan kasus perilaku berisiko penyalahgunaan NAPZA (rokok, alkohol, selain rokok dan alkohol) tertinggi pada Pelayanan Kesehatan Peduli Remaja (PKPR).

Penelitian dimulai pada bulan Januari 2019-Juli 2019 Pelaksanaan intervensi Group Cognitive Behaviour Therapy dilakukan tiga kali seminggu pada tiga kelompok dengan hari yang berbeda-beda pada tiap-tiap kelompok. 


\section{HASIL DAN PEMBAHASAN}

\section{Hasil Analisa Univariat}

Analisa Univariat meliputi karakteristik responden (status tempat tinggal), serta perilaku remaja berisiko penyalahgunaan NAPZA sebelum dan sesudah diberikan tindakan guna mendapatkan nilai mean, serta standar deviasi dari variabel tersebut menggunakan paired sample t-test. Untuk lebih jelasnya dapat dilihat pada uraian berikut:

\section{Gambaran Karakteristik Perilaku Remaja Berisiko Penyalahgunaan NAPZA Berdasarkan Status Tempat Tinggal}

Table.1: Distribusi Frekuensi Karakteristik Remaja Berisiko Penyalahgunaan NAPZA Berdasarkan Status Tempat Tinggal $(\mathrm{N}=64)$

\begin{tabular}{|c|c|c|c|c|c|c|c|c|}
\hline \multirow{3}{*}{ Variabel } & \multirow{3}{*}{ Kategori } & & \multicolumn{4}{|c|}{ Kelompok } & \multirow{2}{*}{\multicolumn{2}{|c|}{ Jumlah }} \\
\hline & & & \multicolumn{2}{|c|}{ Intervensi } & \multicolumn{2}{|c|}{ Kontrol } & & \\
\hline & & & $\mathbf{F}$ & $\%$ & $\mathbf{f}$ & $\%$ & $\mathbf{f}$ & $\%$ \\
\hline & Bersama Orang Tua & & 28 & 87,5 & 26 & 81,2 & 54 & 84,4 \\
\hline Status Tempat Tinggal & $\begin{array}{l}\text { Tidak Bersama Orang } \\
\text { (Kost/Saudara/Teman) }\end{array}$ & Tua & 24 & 12,5 & 6 & 18,7 & 10 & 15,6 \\
\hline
\end{tabular}

Tabel 1.menunjukkan hasil distribusi frekuensi pada 64 responden yang terdiri dari kelompok intervensi maupun kelompok kontrol berdasarkan status tempat tinggal menunjukkan bahwa dengan status tempat tinggal bersama orang tua merupakan responden terbanyak.

\section{Gambaran Rata-Rata Perilaku Remaja Berisiko Penyalahgunaan NAPZA Sebelum dan Sesudah}

diberikan Group Cognitive Behavior Therapy (GCBT) pada Kelompok Intervensi dan Kontrol

Rata-rata perilaku remaja berisiko penyalahgunaan NAPZA sebelum dan sesudah diberikan Group Cognitive Behavior Therapy dianalisis menggunakan paired sample t-test diuraikan pada tabel 2 dan setelah intervensi penelitian, diuraikan pada tabel 3.

Tabel 2 Rata-Rata Perilaku Remaja Berisiko Penyalahgunaan NAPZA Sebelum (Pre-Test) diberikan Group Cognitive Behavior Therapy (GCBT) pada Kelompok Intervensi dan Kelompok Kontrol ( $N=64)$

\begin{tabular}{|c|c|c|c|c|}
\hline \multirow{2}{*}{ Variabel } & \multicolumn{2}{|c|}{ Kelompok Intervensi $(n=32)$} & \multicolumn{2}{|c|}{ Kelompok Kontrol $(n=32$} \\
\hline & Mean & SD & Mean & SD \\
\hline Perilaku remaja berisiko penyalahgunaan NAPZA & 10,50 & 0,84 & 10,34 & 0,75 \\
\hline
\end{tabular}

Tabel 2. menunjukkan rata-rata perilaku berisiko penyalahgunaan NAPZA pada kelompok kontrol lebih rendah dibandingkan pada kelompok intervensi.

.Tabel 3 Rata-rata Perilaku Remaja Berisiko Penyalahgunaan NAPZA Sesudah diberikan Group Cognitive Behavior Therapy (GCBT) pada Kelompok Intervensi dan Kelompok Kontrol (N=64)

\begin{tabular}{ccccc} 
Variabel & Kelompok Intervensi $(\mathbf{n}=\mathbf{3 2})$ & \multicolumn{2}{c}{ Kelompok Kontrol (n=32) } \\
Mean & SD & Mean & SD \\
\hline Perilaku remaja berisiko penyalahgunaan NAPZA & 7,91 & 4,05 & 9,59 & 2,61 \\
\hline
\end{tabular}

Tabel 3 menunjukkan bahwa rata-rata nilai perilaku remaja berisiko penyalahgunaan NAPZA pada kelompok intervensi adalah 7,91 dengan standar deviasi 4,05 yang menunjukkan jarak titik data dengan nilai mean yang cukup besar dikarenakan ada beberapa skor perilaku remaja sesudah diberikan intervensi adalah 0 (tidak berisiko penyalahgunaan NAPZA). Sedangkan perilaku remaja berisiko NAPZA sesudah diberikan Group Cognitive Behaviour Therapy (CGBT) pada kelompok kontrol adalah 9,59 dengan standar deviasi 2,61. Hasil ini menunjukkan bahwa rata-rata perilaku berisiko penyalahgunaan NAPZA sesudah diberikan intervensi pada kelompok intervensi lebih rendah daripada kelompok kontrol.

\section{Analisa Bivariat}

Analisa bivariat ini menggunakan uji t-independen sample t-test untuk melihat perbedaan antara kelompok kontrol dan kelompok intervensi pada masing-masing variabel sebelum dan sesudah diberikan Group Cognitive Behaviour Therapy (CGBT). Hasil analisis selengkapnya sebagai berikut;

Perbedaan Rata-rata Perilaku Berisiko Penyalahgunaan NAPZA Sebelum dan Sesudah diberikan Group Cognitive Behavior Therapy (GCBT) Pada Kelompok Intervensi dan Kelompok Kontrol

Untuk melihat perbedaan perilaku remaja berisiko penyalahgunaan NAPZA sebelum dan sesudah diberikan intervensi pada kelompok intervensi dan kelompok kontrol dilakukan dengan uji independent sample t-test yang dapat dilihat pada tabel.4. 
Wisdia Lola Erwinda, et al, Pengaruh Group Cognitive Behavior Therapy (GCBT) terhadap Perubahan Perilaku Remaja Berisiko Penyalahgunaan NAPZA Berdasarkan StatusTempat Tinggal di Kabupaten Dharmasraya Tahun 2019

Tabel 4 Rata-rata Perilaku Remaja Berisiko Penyalahgunaan NAPZA Sebelum dan Sesudah diberikan Group Cognitive Behavior Therapy (GCBT) pada Kelompok Intervensi dan Kelompok Kontrol ( $\mathrm{N}=64)$

\begin{tabular}{|c|c|c|c|c|c|c|}
\hline \multirow[t]{2}{*}{ Variabel Penelitian } & & \multirow[t]{2}{*}{ Mean } & \multirow[t]{2}{*}{ SD } & \multirow[t]{2}{*}{ P Value } & \multicolumn{2}{|c|}{$\mathbf{C l}$} \\
\hline & & & & & Lower & Upper \\
\hline Kelompok Intervensi & $\begin{array}{l}\text { Sebelum } \\
\text { Sesudah }\end{array}$ & $\begin{array}{l}10,50 \\
7,91\end{array}$ & $\begin{array}{l}0,84 \\
4,05\end{array}$ & 0,001 & 1,13 & 4,05 \\
\hline Selisish & & 2,59 & & & & \\
\hline Kelompok Kontrol & $\begin{array}{l}\text { Sebelum } \\
\text { Sesudah }\end{array}$ & $\begin{array}{c}10,34 \\
9,59\end{array}$ & $\begin{array}{l}0,75 \\
2,61\end{array}$ & 0,124 & -.210 & -.224 \\
\hline Selisih & & 0,75 & & & & \\
\hline
\end{tabular}

Tabel 4 menunjukkan hasil uji $t$ test independent didapatkan $\mathrm{p}<0,05$ pada kelompok intervensi artinya ada perbedaan yang signifikan rata-rata perilaku remaja berisiko penyalahgunaan NAPZA. Sedangkan pada kelompok kontrol hasil uji $t$ test independent didapatkan $p>0,05$ artinya tidak ada perbedaan yang signifikan ratarata perilaku remaja berisiko penyalahgunaan NAPZA.
Perbedaan Rata-Rata Perilaku Remaja Berisiko Penyalahgunaan NAPZA Berdasarkan Status Tempat Tinggal Pada Kelompok Intervensi dan Kontrol

Untuk melihat perbedaan perilaku remaja berisiko penyalahgunaan NAPZA berdasarkan status tempat tinggal pada kelompok intervensi dan kelompok kontrol dilakukan dengan uji independent sample t-test yang dapat dilihat pada table.5.

Tabel 5. Rata-rata Perilaku Remaja Berisiko Penyalahgunaan NAPZA Sebelum dan Sesudah diberikan Group Cognitive Behavior Therapy (GCBT) Berdasarkan Status Tempat Tinggal pada Kelompok Intervensi (N=64)

\begin{tabular}{|c|c|c|c|c|c|c|}
\hline \multirow{2}{*}{ Variabel Penelitian } & & \multirow{2}{*}{ Mean } & \multirow{2}{*}{ SD } & \multirow[t]{2}{*}{ P Value } & \multicolumn{2}{|c|}{ P Value } \\
\hline & & & & & Lower & Upper \\
\hline Status tempat tinggal bersama orang tua & Sebelum & 10,50 & 0,83 & 0,001 & 1,34 & 4,58 \\
\hline Selisish & & 2,96 & & & & \\
\hline Status tempat tingaal tidak bersama orana tua & Sebelum & 10,50 & 1,00 & 0124 & -141 & 141 \\
\hline Selisih & Sesudah & $\begin{array}{c}10,50 \\
0,00\end{array}$ & 0,57 & & & \\
\hline
\end{tabular}

Tabel 5 menunjukkan pada kelompok intervensi skor perilaku remaja berisiko penyalahgunaan NAPZA pada remaja yang tinggal bersama orangtua terjadi penurunan rata-rata dengan nilai $p<0.05$ yang artinya terdapat perbedaan yang signifikan rata-rata perilaku remaja berisiko penyalahgunaan NAPZA sebelum dan sesudah diberikan Group Cognitive Behaviour Therapy (CGBT) pada remaja yang tinggal bersama orangtua. Sedangkan skor perilaku remaja berisiko penyalahgunaan NAPZA pada remaja yang tinggal tidak bersama orangtua tidak terjadi penurunan rata-rata.

\section{Pembahasan}

\section{Karakteristik Responden}

Karakteristik responden pada penelitian ini terdiri dari karakteristik responden berdasarkan status tempat tinggal. Hal ini mengacu pada faktor-faktor yang berhubungan dengan faktor berisiko pada remaja antara lain faktor presdisposing, faktor enabling dan faktor reinforcing. Dari hasil penelitian didapatkan dua kategori status tempat tinggal responden yaitu status tempat tinggal bersama orang tua dan status tempat tinggal tidak bersama orang tua.

Rata-rata Perilaku Remaja Berisiko Penyalahgunaan NAPZA Sebelum diberikan Intervensi Baik Pada Kelompok Kontrol Maupun Kelompok Intervensi.

Hasil penelitian sebelum diberikan intervensi menunjukkan indikasi perilaku berisiko penyalahgunaan NAPZA pada responden yang terlihat sering menggunakan zat atau obat. Zat tersebut berupa rokok, tuak/bir, dan lem/bensin. Hal ini sejalan dengan penelitian (Sitorus, 2014) bahwa pengguna Konsumsi zat adiktif ini sebagai pintu gerbang pada penyalahgunaan narkotika dan psikotropika. Perilaku merokok dan minum alkohol merupakan perilaku yang mendukung seseorang untuk penyalahgunaan narkotika.

Berdasarkan analisa dari hasil kuisioner yang terdapat pada instrument ASMA terlihat indikasi perilaku remaja berisiko penyalahgunaan NAPZA yaitu responden menggunakan zat atau obat karena adanya perasaan bosan, kesepian dan cemas. Hasil penelitian lainnya berdasarkan analisa kuisioner sebelum diberikan intervensi memperlihatkan indikasi berisiko penyalahgunaan NAPZA yaitu responden menggunakan zat atau obat dengan melakukannya sendiri atau keinginan sendiri.

Rata-rata Perilaku Remaja Berisiko Penyalahgunaan NAPZA Sesudah diberikan Intervensi Baik pada Kelompok Kontrol Maupun Kelompok Intervensi

Berdasarkan hasil penelitian yang telah dilakukan, dilihat dari rata-rata perilaku remaja berisiko penyalahgunaan NAPZA sesudah diberikan intervensi mengalami penurunan baik pada kelompok intervensi maupun kelompok kontrol. Dari hasil penelitian setelah diberikan intervensi, terdapat penurunan penggunaan zat/obat pada kelompok intervensi seperti pada penggunaan rokok yang menurun menjadi $78,12 \%$, meminum tuak/ bir menjadi $28,12 \%$, serta tidak ada responden yang menggunakan lem/ bensin dan konsumsi obat tidur. Sejalan dengan penelitian (Carroll et al, 2008) penurunan perilaku ini disebabkan oleh penurunan kebiasaan perokok untuk menggunakan rokok. Cognitive Behaviour Therapy (CBT) juga 
merupakan terapi yang paling sering digunakan terhadap pasien penyalahgunaan NAPZA.

Begitupun pada hasil kuisioner, setelah dilakukan intervensi terdapat perbedaan perilaku berisiko remaja dalam penyalahgunaan NAPZA yang terlihat dari intensitas waktu penggunaan zat atau obat yang semakin menurun dalam satu bulan terakhir. Terdapat penurunan skor rata-rata pada perilaku penyalahgunaan zat atau obat yang disebabkan oleh muculnya rasa sedih, bosan, bingung, kesepian, dan cemas.

Analisa data membuktikan bahwa hipotesis dapat diterima yakni ada perubahan perilaku remaja berisiko penyalahgunaan NAPZA yang signifikan pada kelompok intervensi sebelum dan sesudah dilakukan intervensi Cognitive Behaviour Therapy.

\section{Rata-rata Perilaku Remaja Berisiko Penyalahgunaan NAPZA Berdasarkan Status Tempat Tinggal Sebelum dan Sesudah diberikan Intervensi pada Kelompok Intervensi}

Berdasarkan hasil penelitian yang telah dilakukan, dilihat dari karaktersitik perilaku remaja dengan status tempat tinggal bersama orangtua sebelum dan sesudah diberikan intervensi pada kelompok intervensi, rata-rata perilaku remaja berisiko penyalahgunaan NAPZA mengalami penurunan dari berisiko menjadi tidak berisiko. Sedangkan dilihat dari karaktersitik perilaku remaja dengan status tempat tinggal tidak bersama orang tua sebelum diberikan intervensi pada kelompok intervensi rata-rata perilaku remaja berisiko penyalahgunaan NAPZA tidak mengalami penurunan yang signifikan atau tidak menunjukkan perubahan setelah diberikan intervensi dengan nilai $p>0.05$.

Sejalan dengan penelitian (Afandi dkk, 2009) yang mengatakan bahwa remaja/siswa yang tidak tinggal bersama orangtua (kost/sewa/saudara) lebih berisiko untuk terjerumus dalam penyalahgunaan NAPZA. Hal ini sesuai dengan penelitian menurut (Wresniwiro, 2007) yang mengatakan bahwa remaja yang berisiko tinggi menyalahgunakan NAPZA adalah remaja yang tidak berada dalam pengawasan orangtua, tidak bisa berkomunikasi dengan orangtua, pengendalian dirinya rendah, tidak mau mengikuti aturan norma dan tata tertib, suka mencari sensasi, bergaul dengan penyalahgunaan narkoba, serta rendah penghayatan spiritualnya. Penelitian ini mengkaji bahwa keluarga berkaitan dengan penggunaan dan penyalahgunaan narkoba. Melihat dari keterlibatan keluarga maka keluarga dapat memberikan intervensi untuk pencegahan dan penyalahgunaan narkoba dikalangan anak muda atau remaja.

Sesuai dengan pendapat (Santrock, 2003) yang menyebutkan bahwa remaja yang tidak tinggal dengan orang tua/ di kos jauh dari pengawasan orangtua dalam menjalani kehidupannya akan lebih menekankan pada konformitas dengan tekanan yang bersifat negatif ataupun positif dari orang-orang yang berada disekitarnya. Remaja yang tinggal bersama orang tua dalam hal pengawasan maupun bimbingan lebih ketat karena remaja yang tinggal bersama orang tua lebih sering bertemu dengan orang tuanya sehingga orang tua lebih mengetahui kondisi anaknya. Sedangkan remaja yang tidak tinggal dengan orangtua/ di kos memiliki waktu yang lebih sedikit untuk bertemu orang tuanya dan lebih banyak berinteraksi dengan lingkungan sekitar tempat kos dan lingkungan teman sebayanya di sekolah.

Jika dilihat dari peran orang tua yang berpengaruh pada pembentukan kepribadian dan perilaku anak, terutama anak remaja yang berisiko penyalahgunaan NAPZA yang tinggal bersama orang tua, maka cognitive behaviour therapy dapat digunakan untuk merubah perilaku sesuai dengan tujuan cognitive behaviour therapy menurut (Oemarjoedi,2003) untuk memodifikasi fungsi berpikir, perasaan bertindak dengan menekankan fungsi otak dalam menganalisa, memutuskan, bertanya, berbuat, dan mengambil keputusan kembali. Dengan merubah status pikiran dan perasaannya, klien diharapkan dapat merubah perilaku negatif menjadi positif.

Sesuai dengan hasil penelitian yang menunjukkan cognitive behaviour therapy berpengaruh terhadap perubahan perilaku remaja berisiko penyahgunaan NAPZA pada remaja dengan status tempat tinggal bersama orang tua, hal ini dikarenakan peran penting orang tua dalam memberi pengawasan sehingga perilaku remaja lebih terkontrol serta perubahan pola pikir remaja terhadap perilaku berisiko penyalahgunaan NAPZA.

\section{SIMPULAN}

Berdasarkan status tempat tinggal, sebagian besar responden adalah dengan status tempat tinggal bersama orang tua.. Rata-rata perilaku remaja sebelum diberikan intervensi Group Cognitive Behaviour Therapy berisiko penyalahgunaan NAPZA. Sedangkan rata-rata perilaku remaja sesudah diberikan Group Cognitive Behaviour Therapy menunjukkan ada perbedaan yang signifikan pada kelompok intervensi sedangakan pada kelompok kontroll tidak ada perbedaan yang signifikan. Selain itu, perbedaan yang signifikan setelah diberikan Group Cognitive Behaviour Therapy juga terdapat pada remaja dengan status tempat tinggal bersama orangtua, sedangkan pada remaja dengan status tempat tinggal tidak bersama orang tua tidak terdapat perbedaan yang signifikan.

Oleh karena itu Keperawatan jiwa hendaknya bekerjasama dengan pihak sekolah melalui dinas kesehatan dalam penerapan cognitive behaviour therapy sehingga masalah perilaku berisiko penyalahgunaan NAPZA yang ada di sekolah dapat dicegah. Serta peran keluarga harus lebih diperhatikan dengan cara memperbanyak pengetahuan tentang perilaku berisiko penyalahgunaan NAPZA pada remaja serta cara-cara yang dapat digunakan untuk mengatasi perilaku berisiko pada remaja. Terapis sebaiknya melibatkan orang tua dalam sesi terapi agar orang tua lebih memahami tujuan diberikan cognitive behaviour therapy dalam mencegah perilaku penyalahgunaan NAPZA pada remaja

\section{DAFTAR PUSTAKA}

BNN. (2015) Laporan Akhir Survei Nasional Perkembangan Penyalahgunaan Narkoba Tahun Anggaran 2014. Jakarta - Indonesia.

Peltzer, K., \& Ah, S. (2017) Children and Youth Services Review Concurrent alcohol and cigarette use 
among school-going adolescents in Korea strategies. Children and Youth Services Review, 82(July), 169-176. https://doi.org/10.1016/j.childyouth.2017.09.029.

Sitorus, R. J. (2016). Use of Narcotics Supports Risk Behaviour. Jurnal IImu Kesehatan Masyarakat, $7(1), 1-5$..

Thomas, V. S., \& Rockwood, K. J. (2001). Alcohol Abuse, Cognitive Impairment, and Mortality Among Older People, 415-420.

Sudarsono. (2004). Kenakalan Remaja: Prevensi, Rehabilitasi, dan Resosialisasi. Jakarta: Rineka Cipta.

Willner, P. (2000) Further validation and development of a screening instrument for the assessment of substance misuse in adolescents, 95(March), 1691-1698.

https://doi.org/10.1080/09652140020000920

Martin, P, F. (2010) CBT. Retrieved from http://www.minddisorders.com/BrDel/CognitiveBehavioural-Therapy.html.

Sochting, I. (2004) Cognitive Behavioural Group Therapy, Challanges and Opportunities (First Edit). West Sussex: John Wiley \& Sons, Ltd.

Esposito-smythers, C., Hadley, W., Curby, T. W., \& Brown, L. K. (2017) Behaviour Research and Therapy Randomized pilot trial of a cognitivebehavioural alcohol, self-harm, and HIV prevention program for teens in mental health treatment. Behaviour Research and Therapy, 89, 49-56.https://doi.org/10.1016/j.brat.2016.11.005

Hargiana, G., Keliat, B. A., \& Mustikasari. (2018). The Effect of Cognitive Behavioural Therapy on Heads of Families' Smoking Behaviour and Anxiety. Jurnal Keperawatan Indonesia, 21(2), 117-126. https://doi.org/10.7454/jki.v21i2.770.

Ardashir, A., \& Nazafarin, H. (2018). The Effects of Group Cognitive Behaviour Therapy ( GCBT ) on Suicidal Thoughts in Patients with Major Depression, 16(2), 228-235. https://doi.org/10.5742/MEWFM.2018.93293

Dharma K.K. (2011). Metodologi penelitian keperawatan. Jakarta - Indonesia: Trans Info Media.

Sitorus, R. J. (2014). Komorbiditas Pecandu Narkotika. Jurnal Kesehatan Masyarakat Nasional, Vol. 8.

Carroll, K. M., Ph, D., Ball, S. A., Ph, D., Martino, S., Ph, D.,Rounsaville, B. J. (2008). Therapy for Addiction: A Randomized Trial of CBT4CBT, (July), 881-888.

Afandi, D., Chandra, F., Novitasari, D., Riyanto, I., Kurniawan, L. (2009.) Tingkat Penyalahgunaan Obat dan Faktor Risiko di Kalangan Siswa Sekolah Menengah Umum. Majalah Kedokteran Indonesia (Vol. 59, Nomor 6).

Wresniwiro. (2007). Kecanduan dan Penyalahgunaan Obat-Obatan.

Santrock, J. W. (2003). Perkembangan Remaja. Jakarta: Erlangga.

Oemarjoedi, A. K. (2003). Pendekatan Cognitive Behaviour Dalam Psikoterapi. Jakarta: Kreatif Media. 